\title{
KUALITAS FISIK TELUR PUYUH YANG DIRENDAM DALAM LARUTAN GELATIN TULANG KAKI AYAM DENGAN LAMA PENYIMPANAN YANG BERBEDA
}

\author{
I. JONI, ZULFIKAR DAN T. ADELINA \\ Fakultas Pertanian dan Peternakan Universitas Islam Negeri Sultan Syarif Kasim Riau \\ Kampus II Raja Ali Haji Jln. Soebrantas KM 16 Panam-Pekanbaru \\ Email :indrajoni93@yahoo.com
}

\begin{abstract}
Quail eggs is one of the perishable food. If left in the open air at room temperature, the shelf life ranged between 10-14 days. Preservation is one of the way to prolong shelf life which can be done by soaking the eggs in a gelatin solution. The purpose of the study was to know the physical quality of quail egg soaked in gelatin bone chicken feet long with different time of storage. The experimental design of this study was Complete Randomized Design (CRD) factorial pattern $3 \times 3$ with 5 replications. The first factor was soaking time $(0,30$ and 60 minutes) and the second factor was storage time $(0,15$ and 30 days). The results showed that there was nos ignificant effect of soaking period ( $P>0.05$ ) on egg weight, egg white index, yolk index, Haugh units and $p H$. The longer the storage time, the egg weight, egg white index, yolk index, haugh unit were decreased and the other hand, $p H$ value was increased. Soaking quail eggs in gelatin solution of chicken feet during 30 minutes and storage time for 15 days resulted in $p H$ value almost the same with untreated egg(control).
\end{abstract}

Keywords : quail egg, immersion, gelatin, storage

\section{PENDAHULUAN}

Telur puyuh adalah produk utama yang dihasilkan oleh ternak puyuh dengan nilai gizi yang tinggi dan disukai oleh anak-anak maupun orang dewasa serta harga relatif murah. Direktorat Jenderal Peternakan dan Kesehatan Hewan (2012) melaporkan konsumsi telur burung puyuh per kapita per minggu dari tahun 2009; 2010 dan 2011 mengalami peningkatan, yaitu berturutturut 0,040 kg; 0,043 kg dan 0,052 kg. Permintaan yang semakin meningkat karena masyarakat menyadari keunggulan dan nilai gizi telur puyuh tidak kalah dari telur ayam atau telur bebek. Lukito dkk. (2012) menyatakan telur puyuh merupakan sumber protein dan lemak terbaik. Setiap $100 \mathrm{~g}$ telur puyuh mengandung 15,00 g protein dan 10,20 g lemak. Nilai nutrisi tersebut tidak terlalu berbeda degan telur ayam dan itik, dengan kandungan protein dan lemaknya berturut-turut adalah $12,8 \mathrm{~g}$ dan 11,5 g untuk telur ayam; 13,1 g dan 14,3 $\mathrm{g}$ untuk telur itik.
Telur puyuh memiliki kelemahan yaitu mudah rusak, kerusakan yang sering terjadi berupa kerusakan fisik, kimia dan kerusakan yang diakibatkan oleh mikroba. Menurut Syarief dan Halid (1990) telur yang dibiarkan dalam udara terbuka (suhu ruang) hanya bertahan 10-14 hari, setelah waktu tersebut telur mengalami perubahanperubahan kearah kerusakan seperti terjadinya penguapan kadar air melalui pori-pori kulit telur yang berakibat berkurangnya berat telur, perubahan komposisi kimia dan terjadinya pengenceran putih telur.

Menurut Buckle et al. (1985) kerusakan telur yang terjadi selama penyimpanan antara lain; berkurangnya berat, pertambahan ukuran ruang udara karena air hilang, penurunan berat jenis karena bertambah ruang udara, bercak-bercak pada permukaan kulit telur.

Upaya yang bisa dilakukan untuk memperpanjang daya simpan telur adalah pengawetan. Prinsip dari pengawetan telur 
adalah menutupi pori-pori atau lubanglubang halus yang ada pada dipermukaan kulit telur untuk mencegah penguapan air dan terlepasnya gas-gas lain yang ada di dalam telur, selain itu telur tidak mudah dimasuki oleh mikroba-mikroba yang menimbulkan kerusakan pada telur. Bahanbahan pengawet yang sering digunakan adalah pengawet alami seperti minyak kelapa, kapur sirih, daun jambu biji, daun jati, air teh, kulit bawang merah. Bahanbahan yang bisa digunakan dalam pengawetan telur adalah karet, sabun, gelatin, asam belerang, yang semuanya adalah bahan penutup kulit telur (Syarief dan Halid, 1990).

Gelatin adalah hasil hidrolisis protein kolagen yang diekstraksi dalam air panas yang dikombinasikan dengan perlakuan asam atau basa (Gelatin Manufacture Institute of America Members, 2006). Gelatin salah satu produksi olahan limbah kulit dan tulang ternak. Berdasarkan data dari Gelatin Manufacture Europe (2006) sebagian besar gelatin diproduksi dengan bahan baku kulit babi yang menempati persentase terbesar di dunia yaitu $45,80 \%$; gelatin yang menggunakan kulit sapi $28,40 \%$ dan gelatin dari tulang $24,20 \%$.

Gelatin juga dapat digunakan juga sebagai media pengawet telur segar, dengan prinsip melapisi kulit atau menutupi poripori kulit telur sehingga mempunyai daya simpan yang lebih lama bila dibandingkan dengan tanpa pelapisan. Berdasarkan hasil penelitian Melia dkk. (2009) yang menggunakan gelatin dari tulang sapi, didapatkan hasil bahwa perendaman selama 90 menit dan penyimpanan selama 20 hari memperlihatkan hasil yang terbaik sebagai pengawet telur ayam. Salah satu bahan baku untuk sumber gelatin yang dapat digunakan adalah berasal dari tulang kaki ayam.

Tulang kaki ayam merupakan salah satu hasil samping yang didapatkan di Rumah
Potong Unggas (RPU), Tempat Pemotongan Ayam (TPA) dan pasar tradisional. Potensinya yang melimpah seiring dengan tingginya jumlah pemotongan ayam. Soegiyono (2013) menyatakan jumlah pemotongan ayam di Indonesia pada tahun 2012 sebanyak 1,9 miliar dan meningkat di tahun 2013 menjadi 2,2 miliar ekor. Provinsi Riau melaporkan jumlah pemotongan ayam pada tahun 2012 sebanyak 40.258.000 ekor (Direktorat Jenderal Peternakan dan Kesehatan Hewan, 2012). Dari pemotongan tersebut dapat diasumsikan akan menghasilkan limbah tulang kaki ayam sekitar 80.516.000 potong. Oleh sebab itu ditinjau dari segi ekonomisnya maka pengolahan tulang kaki ayam menjadi gelatin akan memberikan keuntungan yang cukup besar dan juga akan mengurangi kerusakan lingkungan.

Penelitian ini dilakukan untuk mengetahui kualitas fisik (penurunan berat telur, indeks putih telur, indeks kuning telur, haugh unit, dan $\mathrm{pH}$ ) telur puyuh yang direndam dalam larutan gelatin tulang kaki ayam dengan lama penyimpanan yang berbeda.

\section{MATERI DAN METODE}

\section{Tempat dan Waktu}

Penelitian ini dilaksanakan pada bulan Oktober sampai November 2014 di Laboratorium Teknologi Pasca Panen, Ilmu Nutrisi dan Kimia Fakultas Pertanian dan Peternakan Universitas Islam Negeri Sultan Syarif Kasim Riau.

\section{Materi Penelitian}

Bahan yang digunakan dalam penelitian ini adalah : $\mathrm{HCl} 5 \%$, akuades, 45 butir telur puyuh segar, kaki ayam segar sebanyak $10 \mathrm{~kg}$ yang beli di pasar Selasa Panam Pekabaru.

Peralatan yang digunakan adalah: timbangan, pisau, mangkuk stainless, toples 
kaca, saringan, inkubator, kulkas, water bath shaker, gelas piala, gelas ukur, ember, $\mathrm{pH}$ meter, alat tulis, kertas label, aluminium foil, termometer, jangka sorong, cawan petri, kamera digital.

\section{Rancangan Penelitian}

Metode yang digunakan adalah Rancangan Acak Lengkap (RAL) dengan pola faktorial terdiri dari 2 faktor yaitu A adalah lama perendaman dan B lama penyimpanan dengan 5 ulangan untuk setiap perlakuan, masing-masing faktor tersebut adalah :

Faktor A adalah lama perendaman dalam larutan gelatin :

$\mathrm{A}_{1}$ yaitu lama perendaman 0 menit

$\mathrm{A}_{2}$ yaitu lama perendaman 30 menit

$\mathrm{A}_{3}$ yaitu lama perendaman 60 menit

Faktor B adalah lama penyimpanan pada suhu ruang:

$B_{1}$ yaitu penyimpanan selama 0 hari

$B_{2}$ yaitu penyimpanan selama 15 hari

$\mathrm{B}_{3}$ yaitu penyimpanan selama 30 hari

\section{Prosedur Penelitian}

\section{Proses Pembuatan Gelatin}

Proses Pembuatan gelatin dilakukan sesuai metode Zulfikar (2012) yang dimodifikasi dan dipisah menjadi 2 tahap yaitu:

A. Tahap pertama

1. Kaki ayam yang sudah didapat dikupas kulitnya kemudian dibersihkan dari sisa daging dan lemak yang masih menempel.

2. Tulang kaki ayam dipotong kecil ukuran 2-4 cm.

3. Proses penghilangan lemak pada tulang yang kedua dengan cara direbus bersama akuades selama 3 jam di water bath shaker dengan suhu $80^{\circ} \mathrm{C}$ sambil diaduk dengan kecepatan $120 \mathrm{rpm}$.

4. Tulang yang sudah hilang kandungan lemaknya, kemudian dibilas beberapa kali hingga minyak benar-benar bersih, setelah itu tulang direndam dalam $\mathrm{HCl}$ $5 \%$ selama 3 hari.

5. Tulang yang sudah selesai perendaman menggunakan $\mathrm{HCl}$, selanjutnya dinetralkan menggunakan akuades hingga mencapai $\mathrm{pH} \pm 5$.

6. Tulang yang sudah mencapai $\mathrm{pH} \pm 5$ dilakukan pengekstrakan dengan akuades selama 3 jam dengan suhu $80^{\circ} \mathrm{C}$ sambil di aduk dengan kecepatan $120 \mathrm{rpm}$.

B. Tahap kedua

1. Larutan gelatin yang sudah diekstrak lalu didiamkan hingga memekat.

2. Larutan gelatin (rendemen) disaring kemudian disimpan dalam kulkas hingga larutan rendemen menjadi gel.

3. Lalu rendemen tadi dikeringkan menggunakan inkubator selama 72 jam.

4. Larutan gelatin yang sudah mengering dijadikan tepung gelatin.

\section{Proses Perendaman Telur}

1. Persiapan bahan yaitu gelatin yang telah dilarutkan dengan aquades dengan perbandingan $6,67 \%$ gelatin dan $100 \mathrm{ml}$ aquades.

2. Persiapan telur yang sudah dibersihkan dari kotoran yang menempel pada kulit telur sebanyak 45 butir dengan berat 10-12 g.

3. Persiapan tempat perendaman telur yang telah berisi gelatin sebanyak 8 buah yang diberi label sesuai perlakuan, yang mana pada masingmasing terdapat 5 butir telur.

4. Dilakukan pengacakan untuk menentukan telur yang akan diberikan perlakuan pada faktor A (lama perendaman 0, 30 dan 60 menit) dalam gelatin dan faktor B (lama penyimpanan selama 0,15 dan 30 hari).

5. Telur kemudian direndam dalam gelatin selama 30 menit dan 60 menit 
sampai telur terbenam seluruhnya sesuai pengacakkan yang dilakukan.

6. Telur yang sudah direndam kemudian diletakkan pada tempat penyimpanan telur sesuai perlakuan yaitu selama 15 dan 30 hari.

7. Pengujian dilakukan sesuai perlakuan yang ditetapkan.

\section{Peubah yang Diukur}

Peubah yang diukur dalam penelitian ini adalah : Penurunan Berat, Telur Indeks Putih Telur (IPT), Indeks Kuning Telur (IKT), Nilai Haugh Unit (HU) dan Potensial Hidrogen $(\mathrm{pH})$.

\section{Analisis Data}

Analisis data berdasarkan prosedur sidik ragam (ANOVA) dengan model matematika untuk rancangan faktorial yang digunakan menurut Steel dan Torrie (1991).

\section{HASIL DAN PEMBAHASAN}

\section{Penurunan Berat Telur Puyuh}

Hasil analisis sidik ragam memperlihatkan faktor lama perendaman
(0, 30 dan 60 menit) tidak berpengaruh nyata $(\mathrm{P}>0,05) \quad$ terhadap persentase penurunan berat telur puyuh. Kondisi yang berbeda terjadi pada faktor lama penyimpanan, yang mana lama penyimpanan $(0,15$ dan 30 hari) berpengaruh sangat nyata $(\mathrm{P}<0,01)$ terhadap penurunan berat telur puyuh. Hasil sidik ragam juga memperlihatkan tidak terjadinya interaksi antara faktor lama perendaman dan lama penyimpanan terhadap penurunan berat telur puyuh.

Penurunan berat telur yang tertinggi terjadi pada lama penyimpanan 30 hari yaitu sebesar $10,92 \pm 4,68 \%$, kemudian diikuti oleh lama penyimpanan 15 hari sebesar $4,34 \pm 1,03 \%$. Persentase penurunan berat telur yang terendah terjadi pada lama penyimpanan 0 hari sebesar $0,00 \pm 0,00 \%$.

Nilai rata-rata persentase penurunan berat telur puyuh pada perlakuan lama perendaman dan penyimpanan yang berbeda dapat dilihat pada Tabel 1.

Tabel 1. Rata-rata penurunan berat telur puyuh (\%).

\begin{tabular}{ccccc}
\hline Lama & \multicolumn{3}{c}{ Lama Penyimpanan } & Rata-rata \\
\cline { 2 - 4 } Perendaman (menit) & 0 Hari & 15 Hari & 30 Hari & \\
\hline 0 & $0,00 \pm 0,00$ & $4,61 \pm 1,38$ & $12,14 \pm 5,44$ & $5,58 \pm 5,99$ \\
30 & $0,00 \pm 0,00$ & $4,56 \pm 0,60$ & $11,33 \pm 5,69$ & $5,29 \pm 5,68$ \\
60 & $0,00 \pm 0,00$ & $3,87 \pm 1,00$ & $9,29 \pm 3,24$ & $4,39 \pm 4,34$ \\
\hline Rata-rata & $0,00 \pm 0,00^{\mathrm{c}}$ & $4,34 \pm 1,03^{\mathrm{b}}$ & $10,92 \pm 4,68^{\mathrm{a}}$ & \\
\hline
\end{tabular}

Ket: Data disajikan dalam nilai rata-rata dan standard deviasi. Superskrip yang berbeda pada baris (huruf kecil) yang sama menunjukkan pengaruh yang sangat nyata $(P<0,01)$.

Tabel 1 memperlihatkan semakin lama penyimpanan maka semakin tinggi persentase penurunan berat telur puyuh. Hal ini karena selama periode penyimpanan akan terjadi proses difusi yaitu terjadinya penguapan air dan gas $\mathrm{CO}_{2}, \mathrm{NH}_{3}$, dan $\mathrm{N}_{2}$ dari dalam telur sehingga semakin lama waktu penyimpanan maka akan semakin banyak air dan gas yang menguap melalui pori-pori kerabang telur, sehingga akan menyebabkan berkurangnya berat telur. Hal ini kemudian akan berpengaruh terhadap meningkatnya persentase penurunan berat telur puyuh. Hasil penelitian ini sesuai menurut Jazil $d k k$. (2012) semakin lama waktu penyimpanan 
semakin bertambah besar penurunan berat telur. Penurunan berat telur yang terjadi selama penyimpanan disebabkan oleh penguapan air dan pelepasan gas $\mathrm{CO}_{2}$ dari dalam isi telur melalui pori-pori kerabang. Penguapan dan pelepasan gas ini terjadi secara terus menerus selama penyimpanan sehingga semakin lama telur disimpan berat telur akan semakin berkurang. Winarno dan Koswara (2002) menyatakan penurunan berat telur disebabkan karena proses fisiologi berlangsung dengan pesat pada penyimpanan suhu kamar yang mana telur mengalami evaporasi air dan mengeluarkan $\mathrm{CO}_{2}$ dalam jumlah tertentu sehingga semakin lama akan semakin turun kesegarannya.

Lama perendaman dalam larutan gelatin tulang kaki ayam (0, 30 dan 60 menit) tidak berpengaruh nyata $(\mathrm{P}>0,05)$ terhadap persentase penurunan berat telur. Hal ini diperkirakan perendaman dengan larutan gelatin tulang kaki ayam sampai 60 menit belum mampu memperlambat proses pelebaran pori-pori cangkang telur, meskipun gelatin mempunyai sifat lilin yang mengandung berbagai jenis asam amino yaitu : hidroksiprolin, asam aspartat, treonin, serin, asam glutamat, prolin, glisin, alanin, valin, metionin, isoleusin, leusin, tirosin, penilalanin, hidroksilisin, lisin, histidin, dan arganin. Menurut Bahtiyar dkk. (2012) gelatin bersifat multi fungsi yaitu dapat berfungsi sebagai bahan pengisi, pengemulsi (emulsifier), pengikat, pengendap, pemerkaya gizi, pengatur elastisitas, dapat membentuk lapisan tipis yang elastis, membentuk film yang transparan dan kuat, kemudian sifat penting antara lain yaitu daya cernanya yang tinggi dan dapat diatur sebagai bahan pengawet serta bahan penstabil.

Hasil yang didapat pada penelitian ini relatif sama dengan yang dilaporkan Zulfikar (2008) pada telur ayam ras yang direndam dengan ekstrak jahe dalam larutan garam, yang mana lama perendaman $(2,4$ dan 6 hari) tidak berpengaruh terhadap persentase penurunan berat telur ayam ras. Dilain pihak, hasil penelitian ini berbeda dengan yang dilaporkan oleh Zulhendri (2014) pada telur ayam ras yang dioles minyak kelapa sawit dan minyak kelapa, yang mana lama penyimpanan (0, 15 dan 30 hari) dapat memperlambat meningkatnya persentase penurunan berat telur ayam ras.

\section{Indeks Putih Telur Puyuh (Albumen)}

Nilai rata-rata indeks putih telur puyuh pada perlakuan lama perendaman dan penyimpanan yang berbeda dapat dilihat pada Tabel 2.

Tabel 2. Indeks Putih Telur Puyuh (albumen).

\begin{tabular}{ccccc}
\hline Lama & \multicolumn{3}{c}{ Lama Penyimpanan } & Rata-rata \\
\cline { 2 - 4 } Perendaman & 0 Hari & 15 Hari & 30 Hari & \\
\hline 0 Menit & $0,144 \pm 0,012$ & $0,100 \pm 0,010$ & $0,089 \pm 0,007$ & $0,111 \pm 0,026$ \\
30 Menit & $0,153 \pm 0,005$ & $0,096 \pm 0,013$ & $0,088 \pm 0,006$ & $0,112 \pm 0,031$ \\
60 Menit & $0,148 \pm 0,015$ & $0,104 \pm 0,015$ & $0,086 \pm 0,002$ & $0,113 \pm 0,029$ \\
\hline Rata-rata & $0,148 \pm 0,011^{\mathrm{a}}$ & $0,100 \pm 0,012^{\mathrm{b}}$ & $0,087 \pm 0,005^{\mathrm{c}}$ & \\
\hline
\end{tabular}

Ket: Data disajikan dalam nilai rata-rata dan standard deviasi. Superskrip yang berbeda pada baris (huruf kecil) yang sama menunjukkan pengaruh yang sangat nyata $(P<0,01)$.

Hasil analisis sidik ragam memperlihatkan faktor lama perendaman (0, 30 dan 60 menit) tidak berpengaruh nyata $(\mathrm{P}>0,05)$ terhadap perubahan indeks putih telur puyuh. Kondisi yang berbeda terjadi pada faktor lama penyimpanan, yang 
mana lama penyimpanan (0, 15 dan 30 hari) berpengaruh sangat nyata $(\mathrm{P}<0,01)$ terhadap indeks putih telur puyuh. Hasil sidik ragam juga memperlihatkan tidak terjadinya interaksi antara faktor lama perendaman dan lama penyimpanan terhadap indeks putih telur puyuh.

Penurunan nilai indeks putih telur puyuh yang tertinggi terjadi pada lama penyimpanan 30 hari yaitu 0,087; kemudian diikuti oleh lama penyimpanan 15 hari sebesar 0,100. Penurunan nilai indeks putih telur puyuh yang terendah terjadi pada lama penyimpanan 0 hari sebesar 0,148 . Nilai indeks putih telur puyuh dalam penelitian ini masih dalam kisaran normal. Menurut SNI (3926:2008) telur yang masih baru dikeluarkan oleh induknya mempunyai indeks putih telur antara 0,0500,170 dengan angka normal antara 0,0900,120 .

Penurunan nilai indeks putih telur disebabkan gas $\mathrm{CO}_{2}$ yang ada di dalam telur mengalami penguapan terus menerus sehingga kualitas telur menurun. Proses penguapan gas $\mathrm{CO}_{2}$ melalui pori-pori kulit dari albumen menyebabkan perubahan fisik dan kimia, sehingga albumen menjadi berair (encer). Semakin encer putih telur maka semakin rendah ketinggian putih telur. Semakin rendah ketinggian putih telur menunjukkan kualitas telur semakin menurun (Alleoni dan Antunes, 2004). Buckle et al. (2007) menyatakan gas $\mathrm{CO}_{2}$ yang hilang pada putih telur mengakibatkan pengikat cairan putih telur atau ovomucin menjadi rusak. Romanoff dan Romanoff (1963) juga menyatakan hilangnya $\mathrm{CO}_{2}$ melalui pori-pori kerabang telur menyebabkan turunnya konsentrasi ion bikarbonat dalam putih telur dan menyebabkan rusaknya sistem buffer sehingga kekentalan putih telur menurun, akibatnya terjadi penurunan ketinggian albumen. Pori-pori kerabang telur akan melebar seiring bertambah lama penyimpanan sehingga akan menimbulkan kerusakan fisik, kimia dan mikrobologi pada telur.

Hasil yang didapat pada penelitian ini berbeda dengan yang dilaporkan Rahmawati dkk. (2014) pada telur ayam ras yang dilapisi minyak kelapa, kapur sirih dan ekstrak etanol kelopak rosella, berpengaruh terhadap indeks putih telur ayam ras.

\section{Indeks Kuning Telur Puyuh (Yolk)}

Nilai rata-rata indeks kuning telur puyuh pada perlakuan lama perendaman dan penyimpanan yang berbeda dapat dilihat pada Tabel 3.

Hasil analisis sidik ragam memperlihatkan faktor lama perendaman (0, 30 dan 60 menit) tidak berpengaruh nyata $(\mathrm{P}>0,05)$ terhadap perubahan indeks kuning telur puyuh. Kondisi yang berbeda terjadi pada faktor lama penyimpanan, yang mana lama penyimpanan $(0,15$ dan 30 hari) berpengaruh sangat nyata $(\mathrm{P}<0,01)$ terhadap perubahan indeks kuning telur puyuh. Hasil sidik ragam juga memperlihatkan tidak terjadinya interaksi antara faktor lama perendaman dan lama penyimpanan terhadap indeks kuning telur puyuh.

Tabel 3 memperlihatkan semakin lama penyimpanan maka nilai indeks kuning telur puyuh mengalami penurunan atau sudah terjadi kerusakan. Penurunan nilai indeks kuning telur puyuh yang tertinggi terjadi pada lama penyimpanan 15 dan 30 hari yaitu sebesar 0,19 dan 0,18. Penurunan nilai indeks kuning telur puyuh yang terendah terjadi pada lama penyimpanan 0 hari sebesar 0,44 . 
Tabel 3. Indeks Kuning Telur Puyuh (yolk).

\begin{tabular}{ccccc}
\hline Lama & \multicolumn{3}{c}{ Lama Penyimapan } & \multirow{2}{*}{ Rata-rata } \\
\cline { 2 - 4 } Perendaman & 0 Hari & 15 Hari & 30 Hari & \\
\hline 0 Menit & $0,46 \pm 0,01$ & $0,18 \pm 0,01$ & $0,21 \pm 0,07$ & $0,28 \pm 0,13$ \\
30 Menit & $0,43 \pm 0,02$ & $0,20 \pm 0,02$ & $0,18 \pm 0,02$ & $0,27 \pm 0,12$ \\
60 Menit & $0,44 \pm 0,01$ & $0,20 \pm 0,03$ & $0,16 \pm 0,02$ & $0,27 \pm 0,13$ \\
\hline Rata-rata & $0,44 \pm 0,02^{\mathrm{a}}$ & $0,19 \pm 0,03^{\mathrm{b}}$ & $0,18 \pm 0,05^{\mathrm{b}}$ &
\end{tabular}

Ket: Data disajikan dalam nilai rata-rata dan standard deviasi. Superskrip yang berbeda pada baris (huruf kecil) yang sama menunjukkan pengaruh yang sangat nyata $(P<0,01)$.

Nilai indeks kuning telur yang didapat dalam penelitian pada lama penyimpanan 15 hari dan 30 hari adala 0,19 dan 0,18 yang berarti sudah mengalami kerusakan jika dibandingkan SNI (3926:2008), dimana telur yang masih baru mempunyai indeks kuning telur antara 0,050 dan 0,174 dengan angka normal antara 0,90 dan 0,120. Romanoff dan Romanoff (1963) juga melaporkan indeks kuning telur yang baru bervariasi $0,30-0,50$ walaupun pada umumnya 0,39-0,45.

Penurunan indeks kuning telur puyuh pada penelitian ini diperkirakan karena lama waktu penyimpanan telur, selain itu juga diperkirakan dengan lamanya penyimpanan 15 sampai 30 hari maka dapat menyebabkan penurunan kualitas membran vitelin, kerusakan tersebut menyebabkan kuning telur semakin melebar dan mengurangi tinggi kuning telur puyuh. Hal ini sesuai menurut Argo dkk. (2013) bahwa indeks kuning telur dapat dipengaruhi antara lain oleh lama penyimpanan dan kualitas membran vitelin. Kusumawati dkk. (2012) menyatakan semakin lama telur segar disimpan maka nilai indeks kuning telur akan semakin menurun. Hal ini disebabkan karena selama penyimpanan terjadi penguapan $\mathrm{CO}_{2}$ dan $\mathrm{H}_{2} \mathrm{O}$ yang cukup tinggi pada kuning telur sehingga berpengaruh terhadap diameter kuning telur yang semakin membesar. Indrawan dkk. (2012) melaporkan penurunan indeks kuning telur disebabkan oleh membran vitelin kuning telur tidak kuat karena air dari putih telur telah memasuki kuning telur secara difusi sehingga terjadi pembesaran kuning telur dan menjadi lebih lembek.

Hasil yang didapat pada penelitian ini berbeda dengan yang dilaporkan Zulfikar (2008) pada telur ayam ras bahwa perubahan nilai indeks kuning telur dipengaruhi oleh lama perendaman (2, 4 dan 6 hari) tetapi tidak berpengaruh oleh perendaman ekstrak jahe dalam larutan garam. Dilain pihak, hasil penelitian ini sama dengan yang dilaporkan oleh Mukhlisah (2014) bahwa perubahan nilai indeks kuning telur tidak dipengaruhi oleh level ekstrak melinjo (0, 30, 40 dan 60\%) tetapi lama penyimpanan berpengaruh terhadap indeks kuning telur pada setiap perlakuan.

\section{Haugh Unit (HU) Telur Puyuh}

Nilai rata-rata haugh unit telur puyuh pada perlakuan lama perendaman dan penyimpanan yang berbeda dapat dilihat pada Tabel 4 .

Hasil analisis sidik ragam memperlihatkan faktor lama perendaman (0, 30 dan 60 menit) tidak berpengaruh nyata $(\mathrm{P}>0,05)$ terhadap haugh unit telur puyuh. Kondisi yang berbeda terjadi pada faktor lama penyimpanan, yang mana lama penyimpanan $(0,15$ dan 30 hari) berpengaruh sangat nyata $(\mathrm{P}<0,01)$ terhadap haugh unit telur puyuh. Hasil sidik ragam juga memperlihatkan tidak terjadinya interaksi antara faktor lama perendaman dan lama penyimpanan terhadap haugh unit telur puyuh. 
Tabel 4. Nilai Haugh Unit Telur Puyuh.

\begin{tabular}{ccccc}
\hline Lama & \multicolumn{3}{c}{ Lama Penyimpanan } & Rata-rata \\
\cline { 2 - 4 } Perendaman & 0 Hari & 15 Hari & 30 Hari & \\
\hline 0 Menit & $60,87 \pm 0,61$ & $59,82 \pm 0,47$ & $59,09 \pm 0,34$ & $59,93 \pm 0,88$ \\
30 Menit & $61,00 \pm 0,38$ & $59,06 \pm 0,92$ & $59,65 \pm 0,50$ & $59,90 \pm 1,03$ \\
60 Menit & $61,01 \pm 0,60$ & $59,68 \pm 0,44$ & $59,54 \pm 0,25$ & $60,08 \pm 0,85$ \\
\hline Rata-rata & $60,96 \pm 0,50^{\text {a }}$ & $59,52 \pm 0,71^{\mathrm{b}}$ & $59,43 \pm 0,43^{\mathrm{b}}$ & \\
\hline
\end{tabular}

Ket: Data disajikan dalam nilai rata-rata dan standard deviasi. Superskrip yang berbeda pada baris (huruf kecil) yang sama menunjukkan pengaruh yang sangat nyata $(\mathrm{P}<0,01)$.

Tabel 4 memperlihatkan semakin lama penyimpanan maka nilai haugh unit telur puyuh mengalami penurunan atau sudah terjadi kerusakan. Penurunan nilai haugh unit yang tertinggi terjadi pada lama penyimpanan 30 hari yaitu 59,43 $\pm 0,43$, diikuti oleh lama penyimpanan 15 hari sebesar 59,58 $\pm 0,71$. Penurunan nilai haugh unit terendah terjadi pada penyimpanan 0 hari sebesar $60,96 \pm 0,50$.

Nilai haugh unit telur puyuh yang didapat dalam penelitian pada lama penyimpanan 0 hari adalah $60,96 \pm 0,50 ; 15$ hari adalah 59,52 $\pm 0,71$ dan 30 hari adalah $59,43 \pm 0,43$, nilai ini masih dalam kondisi baik jika dibandingkan menurut SNI 01-3926-2006, dimana haugh unit yang didapat tersebut berada pada kisaran mutu II, dan termasuk telur dengan kualitas B. Menurut SNI 01-3926-2006 kesegaran telur dibedakan atas : Mutu I memiliki haugh unit 272; Mutu II memiliki nilai haugh unit 62-72 dan Mutu III memiliki nilai haugh unit $\leq 60$.

Nilai haugh unit telur puyuh akan menurun sejalan dengan lamanya waktu penyimpanan. Jazil dkk. (2012) menyatakan semakin lama penyimpanan nilai haugh unit akan semakin menurun, hal ini terjadi akibat adanya penguapan air dan gas seperti $\mathrm{CO}_{2}$ yang menyebabkan putih telur kental semakin encer. Benyamin et al. (1960) juga menyatakan nilai haugh unit telur yang tinggi menandakan telur masih berkualitas tinggi karena kondisi putih telur kental masih tinggi, namun sebaliknya jika nilai haugh unit telur mulai turun maka kualitas telur pun juga mulai menurun. Penurunan kualitas telur ini sejalan dengan rendahnya tinggi putih telur kental, yang disebabkan terjadinya pengenceran putih telur.

Hasil yang didapat pada penelitian ini berbeda dengan yang dilaporkan Melia dkk. (2009) bahwa interaksi lama perendaman telur ayam ras dalam larutan gelatin kulit sapi (30,60 dan 90 menit) dan lama penyimpanan (10, 20 dan 30 hari) berpengaruh nyata $(\mathrm{P}<0,01)$ terhadap penurunan nilai haugh unit $(84,74 ; 79,95$ dan $75,46)$ telur ayam ras. Mukhlisah (2014) juga melaporkan telur itik yang direndam ekstrak daun melinjo dengan konsentrasi 0, 30, 40 dan 50\% berpengaruh terhadap persentase penurunan nilai haugh unit telur itik berturut-turut yaitu: 95,19; 85,35; 81,35 dan 81,01 . Dilain pihak hasil penelitian ini berbeda dengan yang dilaporkan oleh Zulhendri (2014) bahwa interaksi lama penyimpanan $(0,15$ dan 30 hari) dan jenis minyak oles berpengaruh sangat nyata $(\mathrm{P}<0,05)$ terhadap haugh unit telur ayam ras.

\section{Potensial Hidrogen $(\mathrm{pH})$ Telur Puyuh}

Nilai rata-rata $\mathrm{pH}$ telur puyuh pada perlakuan lama perendaman dan penyimpanan yang berbeda dapat dilihat pada Tabel 5. 
Tabel 5. Potensial Hidrogen (pH) Telur Puyuh.

\begin{tabular}{ccccc}
\hline Lama & \multicolumn{3}{c}{ Lama Penyimpanan } & Rata-rata \\
\cline { 2 - 4 } Perendaman & 0 Hari & 15 Hari & 30 Hari & \\
\hline 0 Menit & $7,37 \pm 0,20^{\mathrm{Ac}}$ & $7,85 \pm 0,22^{\mathrm{Ab}}$ & $762 \pm 0,54^{\mathrm{Ca}}$ & $7,61 \pm 0,39$ \\
30 Menit & $7,28 \pm 0,15^{\mathrm{Abc}}$ & $7,89 \pm 0,16^{\mathrm{Ab}}$ & $8,63 \pm 0,46^{\mathrm{Aa}}$ & $7,93 \pm 0,63$ \\
60 Menit & $7,25 \pm 0,27 \mathrm{Bc}$ & $7,56 \pm 0,44^{\mathrm{Bb}}$ & $8,31 \pm 0,16^{\mathrm{Ba}}$ & $7,70 \pm 0,54$ \\
\hline Rata-rata & $7,30 \pm 0,20$ & $7,76 \pm 0,31$ & $8,18 \pm 0,58$ & \\
\hline
\end{tabular}

Ket: Data disajikan dalam nilai rata-rata dan standard deviasi. Superskrip berbeda pada baris (huruf kecil) dan kolom (huruf besar) yang sama menunjukkan pengaruh yang sangat nyata $(\mathrm{P}<0,01)$.

Hasil analisis sidik ragam memperlihatkan faktor lama perendaman (0, 30 dan 60 menit) berpengaruh sangat nyata $(\mathrm{P}<0,01)$ terhadap $\mathrm{pH}$ telur puyuh. Kondisi yang sama terjadi pada faktor lama penyimpanan, dimana lama penyimpanan $(0,15$ dan 30 hari) berpengaruh sangat nyata $(\mathrm{P}<0.01)$ terhadap $\mathrm{pH}$ telur puyuh. Hasil sidik ragam juga memperlihatkan terjadinya interaksi antara faktor lama perendaman dan lama penyimpanan terhadap $\mathrm{pH}$ telur puyuh.

Lama penyimpanan sampai 30 hari menghasilkan $\mathrm{pH}$ telur yang relatif semakin meningkat meskipun telah direndam dalam larutan gelatin tulang kaki ayam sampai 60 menit. Meskipun demikian $\mathrm{pH}$ yang didapat pada penelitian ini masih berada pada kisaran netral. Fardiaz (1993) mengemukakan nilai $\mathrm{pH}$ telur yang masih baru adalah 7,6, dapat meningkat dalam satu minggu sampai 9,0-9,7. Pada $\mathrm{pH} 9,7$ secara alami putih telur sangat alkalis, kemudian $\mathrm{pH}$ putih telur kembali turun, hal ini disebabkan karena susunan kimia dari telur sudah mulai pecah. Kuning telur mempunyai $\mathrm{pH}$ 6,0, kemudian dapat naik menjadi 6,8 selama penyimpanan, tetapi kenaikannya lebih lambat dari $\mathrm{pH}$ putih telur.

Menurut Romanoff dan Romanoff (1963) ketika telur baru keluar dari induknya mempunyai $\mathrm{pH}$ sekitar 7,6 dan semakin meningkatnya $\mathrm{pH}$ selama penyimpanan. Peningkatan $\mathrm{pH}$ telur disebabkan karena lamanya waktu penyimpanan sehingga gas $\mathrm{CO}_{2}$ akan semakin berkurang di dalam telur karena terjadi penguapan keluar melalui pori-pori telur, maka $\mathrm{pH}$ telur akan meningkat. Hal ini sesuai dengan pendapat Indrawan dkk. (2012) penguapan $\mathrm{CO}_{2}$ dan air dari dalam telur, sehingga akan mengakibatkan $\mathrm{pH}$ telur meningkat.

Muchtadi dan Soegiyono (1992) menyatakan pemecahan asam karbonat dalam albumen menyebabkan perubahan dari keadaan netral (kira-kira $\mathrm{pH}$ 7,6) menjadi keadaan alkali ( $\mathrm{pH} 9,7)$, telur yang kehilangan $\mathrm{CO}_{2}$ dan disertai $\mathrm{pH}$ yang berubah albumen akan menjadi encer. Romanoff dan Romanoff (1963) juga menyatakan berkurangnya gas $\mathrm{CO}_{2}$ yang ada di dalam telur menyebabkan peningkatan $\mathrm{pH}$ sehingga serabut ovumucin yang berfungsi sebagai pengikat cairan putih telur menjadi rusak.

Hasil yang didapat pada penelitian ini relatif sama dengan yang dilaporkan Mukhlisah (2014) pada telur itik yang direndam dalam ekstrak melinjo dengan konsentrasi $0,30,40$, dan 50\% tidak mempengaruhi perubahan nilai $\mathrm{pH}$ putih telur itik berturut-turut yaitu: 8,34; 8,90; 8,75 dan 8,97; sedangkan lama penyimpanan 1, 14, 21 dan 28 harimeningkatkan nilai $\mathrm{pH}$ putih telur. Dilain pihak, hasil penelitian ini berbeda dengan yang dilaporkan Zulfikar (2008) pada telur ayam ras yang direndam dalam larutan garam dengan ekstrak jahe yang berbeda dengan lama perendaman 2, 4 dan 6 hari dan level ekstrak jahe dalam larutan garam 0, 5, 10 dan 15\% tidak berpengaruh terhadap perubahan nilai $\mathrm{pH}$ telur. 


\section{KESIMPULAN DAN SARAN}

\section{Kesimpulan :}

1. Perendaman telur puyuh dalam larutan gelatin tulang kaki ayam tidak mampu mempertahankan kualitas fisik (penurunan berat telur, indeks putih telur, indeks kuning telur, haugh unit dan $\mathrm{pH}$ ).

2. Perendaman telur puyuh dalam larutan gelatin tulang kaki ayam selama 30 menit dan lama penyimpanan 15 hari menghasilkan nilai $\mathrm{pH}$ yang mendekati nilai $\mathrm{pH}$ telur puyuh kontrol (lama perendaman 0 menit dan lama penyimpanan 0 hari.

\section{Saran}

Disarankan melakukan penelitian lanjutan dengan memperpanjang waktu perendaman telur puyuh dalam larutan gelatin tulang kaki ayam dan meningkatkan persentase gelatin tulang kaki ayam untuk mempertahankan kualitas fisik maupun kimia telur puyuh.

\section{DAFTAR PUSTAKA}

Alleoni, A. C. C. and A. J. Antunes, 2004. Albumen Foam Stability And Sovalbumin Contents In Eggs Coated With Whey Protein Concentrate. Universidade do Norte do Parana, UNOPAR, Londrina.

Apriyantono, H. A. 2003. Makalah halal: kaitan antara syar'i, teknologi, dan sertifikasi. www.indohalal.com/doc-halal2.html.

Argo, L. B., Tristiarti, dan I. Mangisah. 2013. Kualitas fisik telur ayam arab petelur fase I dengan berbagai level azolla microphylla. Animal Agricultural Journal, 2(4): 445-457.

Badan Standarisasi Nasional. 2006. SNI 01-39262006. Telur Ayam Konsumsi. Dewan Standarisasi Nasional. Jakarta.

Badan Standarisasi Nasional. 2008. SNI 01-39262008. Telur Ayam Konsumsi. Dewan Standarisasi Nasional. Jakarta.
Bahtiyar, M. I., A. Z. Al-husna, dan Y. L. Fradita. 2012. Pemanfaatan tulang sisa rumah makan, rumah potong hewan dan rumah potong ayam sebagai bahan pembuatan gelatin. Jurnal of ISMAPETI, 1(2): 12-20.

Benyamin, E. W., J. M. Gwin., F. L. Faber and W. D. Termohlen. 1960. Marketing Poultry Product. The $5^{\text {th }}$ Ed. John Wiley and Sons, Inc. New York.

Buckle, K. A., R. A. Edwards, G. H. Fleed, dan M. Wooton. 1985. Ilmu Pangan. Terjemahan Hari Purnomo dan Adiono. Universitas Indonesia Press. Jakarta.

Buckle, K. A., R. A. Edwards, G. H. Fleet, and M. Wooton. 2007. Food science. International Development Program of Australian University and Colleges. Australia

Direktorat Jenderal Peternakan dan Kesehatan Hewan. 2012. Data statistik peternakan dan kesehatan. Kementerian Pertanian Republik Indonesia. Jakarta.

Fardiaz, S. 1993. Analisis Mikrobiologi Pangan .Penerbit PT Raja Grafindo, Jakarta.

Fatimah, D. dan A. Jannah. 2008. Evektivitas penggunaan asam sitrat dalam pembutan gelatin tulang ikan bandeng (Chanos-chanos forskal). Skripsi. Jurusan Kimia, Fakultas Sains dan Teknologi, Universitas Islam Negeri Maulana Malik Ibrahim, Malang.

Gelatin Manufactures Institute of America (GMIA). 2012. Gelatin Handbook. Gelatin Manufactures Institute of America. http://www.gelatin.gmia.com/images/GMI A_Gelatin_Manual_2012.pdf. Diakses 18 maret 2014.

Gelatin Manufacture of Europe (GME). 2006. Market Data Gelatin 2001, 2002, 2003. http://www.gelatine.org/. [10 Maret 2014]. 22:00 PM.

Indrawan, I. G., I. M. Sukada, dan I. K. Suada. 2012. Kualitas telur dan pengetahuan masyarakat tentang penanganan telur di tingkat rumah tangga. Jurnal Indonesia Medicus Veterinus, 1(5): 607-620. 
Jazil, N., A. Hitono, dan S. Mulyani. 2012. Penurunan kualitas telur ayam ras dengan intensitas warna coklat kerabang berbeda selama penyimpanan. Jurnal Aplikasi Teknologi Pangan 2(1): 43-47.

Kurtini, T., K. Nova, dan D. Septinova. 2011. Produksi Ternak Unggas. Anugrah Utama Raharja (AURA) Printing dan Publishing. Bandar Lampung.

Kusumawati, E., M. D. Rudyanto, dan I. K. Suada. 2012. Pengasinan mempengaruhi kualitas telur itik mojosari. Jurnal Indonesia Medicus Veterinus, 1(5): 645-656.

Lukito. G. A., A. Suwarastuti, dan A. Hintono. 2012. Pengaruh berbagai metode pengasinan terhadap kadar $\mathrm{NaCl}$, kekenyalan dan tingkat kesukaan konsumen pada telur puyuh asin. Animal Agriculture Journal, 1(1): 829-838.

Melia, S., I. Juliyasri dan Africon. 2009. Teknologi pengawetan telur ayam ras dalam larutan gelatin dari limbah kulit sapi. Hasil penelitian. Fakultas Peternakan Universitas Andalas. Padang.

Muchtadi, T, R. dan Soegiyono. 1992. Ilmu Pengetahuan Bahan Pangan. Depertemen Pendidikan dan Kebudayaan Direktorat Jendral Pendidikan Tinggi Pusat Antar Universitas Pangan dan Gizi Institut Pertanian Bogor. Bogor.

Mukhlisah, A. N. 2014. Pengaruh level ekstrak daun melinjo (Gnetum gnemon Linn) dan lama penyimpanan yang berbeda terhadap kualitas telur itik. Skripsi. Fakultas Peternakan. Universitas Hasanuddin, Makassar.

Rahmawati, S., T. R. Setyawati, dan A. H. Yanti. 2014. Daya simpan dan kualitas telur ayam ras dilapisi minyak kelapa, kapur sirih dan ekstrak etanol kelopak rosella. Jurnal Protobiont, 3(1): 55-60.

Romanoff. A. L. and A. J. Romanoff. 1963. 2nd. Ed. The Avian Egg. John Wiley and Sons, New York.
Sarwono. 2004. Pengawetan dan Pemanfaatan Telur. Penebar Swadaya. Jakarta.

Soegiyono. 2013. Permintaan Ayam Ras Broiler Naik15,8\%.www.

livestockreview.com/2013/01/permintaanakan-ayam-ras-broiler-naik-150-di2013.

[Diakses Pada Tanggal 12 Maret 2014].

Stadelman, W. J. and O. J. Cotterill. 1995. Egg Science and Technology. 4 Ed. Food Products Press an Imprint of The Haworth Press, Inc., New York.

Steel, R. G. dan J. H. Torrie. 1991. Prinsip dan Prosedur Statistika Suatu Pendekatan Biometrik. Edisi 2 cetakan 2. Alih bahasa Bambang Sumantri. PT. Gramedia Pustaka Utama, Jakarta.

Syarief dan H. Halid. 1990. Buku Monograf Teknologi Penyimpanan Pangan. Laboratorium Rekayasa Pangan dan Gizi, Institut Pertanian Bogor. Bogor.

Winarno, F. G. dan S. Koswara. 2002. Telur : Komposisi, Penanganan dan Pengelolaan. Institut Pertanian Bogor. Bogor.

Yuwanta, T. 2004. Dasar Ternak Unggas. Kanisius :Yogyakarta.

Zulfikar. 2008. Sifat fisik dan organoleptik telur ayam ras hasil perendaman dalam campuran larutan garam dengan ekstrak jahe yang berbeda. Skripsi. Fakultas Peternakan. Institut Pertanian Bogor. Bogor.

Zulfikar. 2012. Penilaian kualitas gelatin kaki ayam pedaging tua dan residu daging ayam tanpa tulang. Disertasi. Universitas Kebangsaan Malaysia.

Zulhendri. 2014. Mutu fisik telur ayam dengan pengolesan minyak kelapa sawit dan kelapa selama penyimpanan pada suhu kamar. Skripsi. Fakultas Pertanian dan Peternakan, Universitas Islam Negeri Sultan Syarif Kasim Riau. Pekanbaru. 